УДК 658.1

\title{
ФІНАНСОВИЙ РИЗИК ПРИ ФОРМУВАННІ СТРАТЕГІЇ СТАЛОГО РОЗВИТКУ ПІДПРИЕМСТВА
}

\section{FINANCIAL RISK IN THE FORMATION OF A STRATEGY FOR SUSTAINABLE DEVELOPMENT OF THE ENTERPRISE}

\author{
Березянко Тамара Володимирівна \\ доктор економічних наук, \\ Національний університет харчових технологій \\ ORCID: https://orcid.org/0000-0001-9228-4239 \\ Костриця Олександра Валентинівна \\ магістрантка, \\ Національний університет харчових технологій \\ ORCID: https://orcid.org/000-0002-0369-0284 \\ Дорошенко Владислав Олександрович \\ Національний університет харчових технологій \\ ORCID: https://orcid.org/0000-0002-5371-2832
}

\author{
Berezianko Tamara, Kostrytsia Oleksandra, Doroshenko Vladyslav \\ National University of Food Technologies
}

\begin{abstract}
Стаття присвячена теоретичним та практичним аспектам з формуванню програми сталого розвитку при наявності фрінансових ризиків на підприємстві. Проаналізовані різні поняття науковців, щодо таких термінів: «ризик», «фрінансовий ризик» та «сталий розвиток підприємства». Розглянуто основні складові сталого розвитку підприємства та вплив на нього фрінансового ризику. Проаналізовано ринок продуктів сухих сніданків в Україні та рівень фрінансового стану досліджуваного підприємства ПрАТ «Лантманнен Акса», Проаналізовано вплив всіх фрінансових показників та наявність фрінансових ризиків. Запропоновано заходи щодо зниження фрінансових ризиків, створено нова програма сталого розвитку ПрАТ «Лантманнен Акса».

Ключові слова: сталий розвиток, підприємство, фрінансовий стан, ризик, показник, коефріцієнт, рентабельність, ринок.

Статья посвящена теоретическим и практическим аспектам формирования программы устойчивого развития при наличии фринансовых рисков на предприятии. Проанализированы разные понятия ученых относительно таких терминов: «риск», «финансовый риск» и «устойчивое развитие предприятия». Рассмотрены основные составляющие устойчивого развития предприятия и влияние финансового риска. Проанализированы рынок продуктов сухих завтраков в Украине и уровень фринансового состояния исследуемого предприятия ЧАО «Лантманнен Акса», Проанализировано влияние всех фринансовых показателей и фринансовых рисков. Предложены меры по снижению финансовых рисков, создана новая программа устойчивого развития ЧАО «Лантманнен Акса».
\end{abstract}

Ключевые слова: устойчивое развитие, предприятие, фринансовое состояние, риск, показатель, коэфрфицциент, рентабельность, рынок.

The article is devoted to theoretical and practical aspects of forming a sustainable development program in the presence of financial risks in the enterprise. Different concepts of scientists regarding the following terms are analyzed: "risk", "financial risk" and "sustainable development of the enterprise". The relevance of the implementation of sustainable development programs by enterprises is determined and the implementation of sustainable development programs at enterprises allows to obtain additional advantages in management and to react quickly to changes in the internal and external environment of the enterprise. The indicators of the economic, social and environmental spheres of the enterprise are considered, which allow us to assess the state of the organization in terms of sustainability, and the calculation of the indicators indicated in the article allows us to find the disproportions in the management of sustainable development of the enterprise and to see in which spheres, economic, social or 
ecological, is more active work to achieve sustainability. The main components of sustainable development of the enterprise and the impact of financial risk on it are considered. The market of breakfast cereals in Ukraine is analyzed, it can be stated that today the market is at a fairly high level of demand, which allows the company to operate successfully and the level of financial condition of the researched enterprise PJSC "Lantmann Aksa". looking at the limitations through COVID-19. It is determined that to develop a strategy to improve sustainable development, you must first assess the financial condition of the enterprise, using SWOT-analysis, calculation of financial performance, for which the following analyzes were developed: horizontal, vertical, comparative and financial ratios, profitability and level bankruptcy. The impact of all financial indicators and the presence of financial risks are analyzed, it is the sustainable development program that directly depends on these indicators, they help to accumulate free funds for its development, so the concepts of financial development and sustainable development are directly proportional. Measures to reduce financial risks have been proposed, and a new program for the sustainable development of PJSC Lantmann Aksa has been created, which allows bringing the company to a new level.

Keywords: sustainable development, enterprise, financial condition, risk, indicator, coefficient, profitability, market.

Постановка проблеми. На сьогоднішній день, коли ринок харчової промисловості розвивається вкрай швидко, керівництву підприємств постає не легка задача - забезпечувати зміни, задля того, щоб зберегти конкурентні переваги, а не тільки зберегти своє місце на ринку.

Підприємства вимушені орієнтуватись на стратегію управління, яка б дозволила підвищити фрінансово-економічну ефективність, а також не забувати про природо- та ресурсозбереження. Саме через це - покращення концепції управління сталим розвитком управління $\epsilon$ найнеобхіднішим для сучасного підприємства, щоб залишатись конкурентоспроможним.

Фінансова-економічна ефективність підприємства залежить від наявності фрінансових ризиків. Кожен день підприємства зіштовхуються 3 тим, що потрібно приймати доволі складні рішення, які мають ризиковий характер, що можуть за собою нести фрінансові втрати, тому багато підприємств шукають шляхи для встановлення фрінансової стабільності. Для того щоб віднайти фінансову стабільність та мінімізувати негативний вплив фрінансових ризиків та не допустити його реалізацію потрібно постійно прогнозувати ймовірність його настання та робити оцінку постійних фракторів, які впливають на фрінансову середу підприємств.

Розуміння принципів фрінансово-економічної складової сталого розвитку підприємства дає можливість вже на ранніх стадіях здійснити зміни, що в перспективі призведуть до позитивних результатів. Тому актуальною потребою постає вирішення питання фрормулювання фрінансово-економічної складової та описування її в концепції сталого розвитку як основи вибору та затвердження управлінського механізму забезпечення стійкості.

Аналіз останніх досліджень і публікацій. Над проблематикою фрінансових ризиків багато років працюють різні вчені, а саме: С. Біра [1], Х. Фрімен [2], Н.В. Васюк
[3], Х.Р. Гальчак [4], Л.М. Демиденко [5], Я.І. Невмержицький [6], Ю.С. Скакальський [7], О.А. Зоріна [8] та інші. Однак саме фрінансово-економічна складова сталого розвитку та вплив на нього фрінансового ризику не була досліджена достатньо і потребує більш глибокого аналізу і висвітлення даного питання.

Формулювання цілей дослідження. Ціллю написання $€$ запропонування шляху удосконалення фрінансово-економічного аспекту стратегії сталого розвитку підприємства на основі аналізу фонансових ризиків підприємства «Лантманнен Акса».

Виклад основного матеріалу дослідження. Забезпечення сталого розвитку підприємства $€$ невід'ємною частиною успіху кожного виробництва. Зокрема, управління стійким розвитком потребує постійної посиленої орієнтації на соціально-економічне зростання, i, як результат, підвищення ефективності фрункціонування.

Концепція сталого розвитку визначає певний комплексний підхід до фрункціонування організацій, що передбачає взаємозв'язок та інтеграцію економічного, екологічного та соціального аспектів діяльності, при якому темпи економічного процвітання підприємства $\epsilon$ тотожними темпам відтворення природних ресурсів задля не лише 3 метою власних інтересів, а також задля можливості задоволення потреб наступним поколінням.

Загалом, сталий розвиток - це антикризовий, невпинний, стабільний та підконтрольний процес, якому притаманне зростання економічної ефективності діяльності підприємства 3 паралельним посиленням сорери відповідальності перед клієнтами та партнерами, а також розробленими заходами щодо охорони навколишнього середовища, спрямованими на покращення якості життя як для теперішнього, так і наступного покоління [9].

На думку деяких сучасних американських науковців, ризик - ймовірність настання збит- 
ків та втрат [10, с. 448]. У відомих словниках Вебстера та Ожегова "ризик" описується як "небезпека, можливість збитку або настання втрат" та "можливість небезпеки" або "дія навмання зі сподіванням на щасливий вихід". Також вітчизняні автори, дають визначення: ризик - ймовірність (загроза) втрати підприємством частини своїх ресурсів, недоотримання прибутків або появи додаткових витрат внаслідок певної виробничої та фрінансової діяльності [11, с. 58].

Також важливо відмітити, що ризик характеризується не тільки з втратами, але й також несе можливість отримати незапланований прибуток. Ця закономірність має дві сторони з прямим та зворотним змістом.

Пряме розуміння - це фрінансового вигода після прийнятого рішення, зворотне розуміння - понесені фрінансові та матеріальні збитки.

Також потрібно наголосити на тому, що неоднозначна ситуація може і не призвести до ризику. Ризикові ситуації можуть стосуватися окремих або груп осіб, які приймають рішення, коли майбутні події, які мають вели- кий шанс трапитись, вплинуть на результати їх рішень. 3 цього переліку можна зробити висновок, що ризик є невизначеністю наслідків, у разі настання яких підприємство може як отримати додатковий прибуток, або зазнати великих ризиків.

Відповідно, основні характеристики ризику $€$ невизначеність, альтернативність та неузгодженість. На кожному підприємстві фрінансові ризики мають величезну різноманітність.

Фінансово-економічний стан - одна 3 найважливіших характеристик діяльності підприємства. Він залежить від результатів виробничої, комерційної та фрінансово-господарської діяльності підприємства.

Аналіз фрінансового стану підприємства $€$ необхідним, оскільки дає інфрормацію про якісну та кількісну оцінку зміни показників у динаміці і допомагає керівництву прийняти управлінські рішення щодо планування і прогнозування діяльності в довгостроковому та короткостроковому періодах.

Для оцінки стану фрінансово-економічного показнику підприємств існує декілька методів, які описані в таблиці 1.

Характеристика основних методів оцінки фрінансово-економічного стану

\begin{tabular}{|c|c|}
\hline Метод & Характеристика \\
\hline 1 & 2 \\
\hline Горизонтальний & $\begin{array}{l}\text { Відображає не постійний характер використання фрінансових показників, } \\
\text { оскільки виконується порівняння із минулими періодами. При } \\
\text { горизонтальному аналізі використовуються такі підходи: зіставлення } \\
\text { змін в абсолютних величинах (гривні) та порівняння змін у відносних } \\
\text { (відсоткових) величинах. }\end{array}$ \\
\hline Вертикальний & $\begin{array}{l}\text { Основа структурного аналізу, оскільки спроможний визначити структуру } \\
\text { показників в аналітичних таблицях, фрінансової звітності та інших її варіантах } \\
\text { завдяки виявлення динаміки зміни показників за аналізований період. }\end{array}$ \\
\hline $\begin{array}{l}\text { Порівняльний } \\
\text { срінансовий аналіз }\end{array}$ & $\begin{array}{l}\text { Основується на порівнянні значень окремих груп схожих показників } \\
\text { між собою. При даному аналізі прораховуються розміри абсолютних та } \\
\text { відносних відхилень порівнюваних показників. }\end{array}$ \\
\hline $\begin{array}{l}\text { Аналіз фрінансових } \\
\text { коедріцієнтів } \\
\text { (R-аналіз) }\end{array}$ & $\begin{array}{l}\text { Коефріцієнти оцінки фрінансової стійкості підприємства показують рівень } \\
\text { орінансового ризику, який має зв'язок зі структурою джерел формування } \\
\text { капіталу підприємства } \\
\text { Коефріцієнти оцінки платоспроможності (ліквідності). Аналіз } \\
\text { платоспроможності є ключовим фрактором фрінансового аналізу. } \\
\text { Коефріцієнти оцінки оборотності активів. Ці показники відображають } \\
\text { швидкість оборотності коштів підприємства. Коефріцієнти оборотності } \\
\text { показують кількість оборотів, що здійснюються за аналізований термін } \\
\text { і тривалість одного обороту, що характеризує середній термін, за який } \\
\text { відбувається оборот. } \\
\text { Коефіцієнти оцінки рентабельності (прибутковості) характеризують } \\
\text { ефективність всієї діяльності підприємства з урахуванням фракторів ризику. }\end{array}$ \\
\hline $\begin{array}{l}\text { Інтегральний } \\
\text { фрінансовий аналіз }\end{array}$ & $\begin{array}{l}\text { Сьогодні, одним з найпопулярніших інструментів у використанні } \\
\text { фрінансових менеджерів, є SWOT-аналіз - цей метод постійно } \\
\text { використовується у стратегічному плануванні діяльності організації, що } \\
\text { заключається у поділі фракторів та явищ на чотири категорії. }\end{array}$ \\
\hline
\end{tabular}


Звичайно, у кожного метода є свої недоліки та переваги, тому кожне підприємство задля есрективного ведення орінансово-економічної діяльності має систематично проводити детальний аналіз та оцінку фрінансово-економічного стану за допомогою різних методів і прийомів, які вже адаптовані під стиль цього підприємства і відповідають стратегії та політиці його розвитку.

Проаналізуємо економічний стан досліджуваного підприємства ПрАТ «Лантманнен Акса».

Для повного аналізу потрібно оцінити ринок сухих сніданків.

Сухі сніданки - мюслі з'явилися в Україні в кінці 20-го століття та зайняли стійку позицію на ринку харчових продуктів. Мюслі припали до душі багатьом українцям, через швидке приготування і великої поживності.

Багато виробників роблять ставку на те, що мюслі - невід'ємна частина раціону всіх, хто слідкує за вагою. Рослинні волокна, які є у складі мюслей повільно перетравлюються в шлунку, що дозволяють довгий час не відчувати голод.

Ринок фрасованих круп в Україні $\epsilon$ дуже розвинений. За останні роки, за даними аналізу інорормації Держслужби статистики, щорічне виробництво усіх видів круп становило близько 380 тис [13]. Виробництво деяких круп сильно збільшилася. Якщо раніше на першому місці була гречана крупа, яка має найбільший попит у населення, то зараз ії частка становить близько 19-20\% у сумарному обсязі виробництва круп, тоді як найвищу питому вагу в цій структурі займають зерна зернових культур плющені, перероблені в пластівці, лущені, обрушені, різані або подрібнені [14].

Пластівці стрімко заполоняють територію круп. Каші - щоденний продукт харчування для кожного українця, який з'явився задовго до появи борошна. Ще тисячі років тому наші предки переробляли просо, жито, ячмінь і пшеницю. Сьогодні важко уявити українця, який не мав би у своєму раціоні трьохчотирьох видів каш, найпопулярнішими з яких $€$ гречка, рис та вівсянка [15].

Рівень споживання пластівців щороку зростає на 8-9\%.

AXA - міжнародний бренд, що розпочав свою історію у 1890 році в Швеції, а сьогодні $\epsilon$ частиною великого скандинавського холдингу Lantmännen.

Основними видами продукції, що виробляє Товариство $є$ сухі сніданки TM «START», TM «AXA» та каші миттєвого приготування TM «AXA». Беручи до уваги асортимент підприємства, можемо зробити висновок щодо того, що 82 найменування в номенклатурі задовольняє потреби існуючого сегменту ринку: дешеві товари, представлені у таких категоріях як каші швидкого приготування, гранола, мюслі, подушечки, пластівці та батончики орієнтовані на невибагливого споживача, який прагне до різноманіття в доступному ціновому сегменті.

Після ознайомлення з ринком сухих сніданків, далі потребується провести фрінансовий та SWOT-аналізи.

Розглянемо основні техніко-економічні показники ПрАТ «Лантманнен Акса» за 2018-2020 роки (табл. 2).

За останні роки на ПрАТ «Лантманнен Акса» прослідковується позитивна динаміка по таким показникам: чистий дохід від реалізації продукції більше на 20\%, також за допомогою нового обладнання в 2020 році спостерігається зниження собівартості продукції на 10093 тис. грн., що у відсотках $(-2,59 \%)$, рентабельність активів зросло на 0,82\%, що свідчить про ріст попиту на продукцію підприємства. Для повної оцінки потрібно ще проаналізувати показники фрінансового стану підприємства (табл. 3).

На 2020 рік підприємство вивело коефріцієнт абсолютної ліквідності до нормативного стану 0,16, що свідчить про ефрективну стратегію управління фрінансовими ресурсами.

Коефріцієнт швидкої ліквідності - за 2018-2020 роки можна стверджувати, що підприємство здатне погашати поточні зобов'язання за умови своєчасного здійснення розрахунків з дебіторами.

Коесріцієнт платоспроможності (автономії) за 2 роки підприємство його вивело на нормативний показник у 0,52. Можна стверджувати, що компанія змогла подолати певні фрінансові ризики.

Коефріцієнт забезпеченості власними оборотними засобами у 2020 рік, можна побачити, що показник зріс до 0,16, тому підприємство працює у вірному напрямку, і навіть у моменти кризи підприємство зможе працювати та виробляти товари.

Фінансова діяльність - допомагає забезпечити срінансове фрункціонування підприємства та досягти поставлених цілей.

Першим кроком до оцінки ефрективності управління ризиками фрінансової діяльності $€$ визначення типу економічної стійкості підприємства. Відповідно до показника забезпечення запасів і витрат власними та позиченими коштами можна назвати такі типи фрінансової стійкості підприємства (табл. 4). 
Таблиця 2

Основні техніко-економічні показники виробничо-господарської діяльності ПрАТ «Лантманнен Акса» за 2018-2020 рр

\begin{tabular}{|l|c|c|c|}
\hline \multicolumn{1}{|c|}{ Показники } & \multicolumn{2}{c|}{ Роки } \\
\cline { 2 - 4 } & $\mathbf{2 0 1 8}$ & $\mathbf{2 0 1 9}$ & $\mathbf{2 0 2 0}$ \\
\hline \multicolumn{1}{|c|}{$\mathbf{1}$} & $\mathbf{2}$ & $\mathbf{3}$ & $\mathbf{4}$ \\
\hline Чистий дохід від реалізації продукції, тис. грн. & 468946 & 552655 & 574979 \\
\hline Середньооблікова чисельність штатних працівників, осіб & 221 & 260 & 262 \\
\hline Фонд оплати праці штатних працівників, тис. грн. & 53556 & 74182 & 84734 \\
\hline Продуктивність праці, тис. грн./особу & 2121,9 & 2125,6 & 2194,6 \\
\hline Середньомісячна оплата праці, грн./особу & 20,2 & 23,8 & 26,9 \\
\hline Середньорічна вартість основних засобів, тис. грн & 53235 & 104035 & 108332 \\
\hline Фондовіддача, грн./грн. & 8,80 & 5,312 & 5,307 \\
\hline Коесріцієнт оборотності оборотних коштів & 2,6 & 3,1 & 3,4 \\
\hline Середньорічна вартість активів, тис. грн. & 231846,5 & 275662 & 296472 \\
\hline Середньорічна вартість власного капіталу, тис. грн. & 77361,5 & 105375,5 & 137834,5 \\
\hline Собівартість реалізованої продукції, тис. грн. & 324721 & 389726 & 379633 \\
\hline Повні витрати на виробництво, тис. грн. & 424125 & 514949 & 504994 \\
\hline Витрати на 1 грн. реалізованої продукції, коп. & 69,2 & 70,5 & 66,0 \\
\hline Прибуток від реалізації продукції, тис. грн. & 31800 & 37838 & 43994 \\
\hline Чистий прибуток (збиток), тис. грн. & 25683 & 30383 & 35103 \\
\hline Рентабельність діяльності, \% & 5,60 & 5,49 & 6,10 \\
\hline Рентабельність продукції, \% & 7,50 & 6,8 & 7,6 \\
\hline Рентабельність власного капіталу, \% & 28,4 & 25,2 & 22,6 \\
\hline Рентабельність активів, \% & 11,07 & 11,02 & 11,84 \\
\hline
\end{tabular}

Джерело: складено авторами на основі даних підприємства

Таблиця 3

Показники фрінансового стану ПрАТ «Лантманнен Акса» за 2018-2020 рр.

\begin{tabular}{|c|c|c|c|c|}
\hline Показник & $\begin{array}{l}\text { Нормативне } \\
\text { значення }\end{array}$ & 2018 & 2019 & 2020 \\
\hline \multicolumn{5}{|c|}{ Показники ліквідності підприємства } \\
\hline Коеоріцієнт покриття & $>1$ & 2,97 & 2,39 & 2,47 \\
\hline Коефріцієнт швидкої ліквідності & $0,6-0,8$ & 2,16 & 1,72 & 1,85 \\
\hline Коефріцієнт абсолютної ліквідності & $>0$ збільшення & 0,31 & 0,004 & 0,16 \\
\hline Чистий оборотний капітал, тис. грн. & $>0$ збільшення & 120281 & 103827 & 99517 \\
\hline \multicolumn{5}{|c|}{ Показники платоспроможності (фрінансової стійкості) підприємства } \\
\hline Коефріцієнт платоспроможності (автономії) & $>0,5$ & 0,35 & 0,44 & 0,52 \\
\hline Коефріцієнт орінансування & $<1$ зменшення & 3,1 & 2,9 & 3,3 \\
\hline $\begin{array}{l}\text { Коефріцієнт забезпеченості власними оборотними } \\
\text { засобами }\end{array}$ & $>0,1$ & 0,11 & 0,01 & 0,16 \\
\hline Коефріцієнт маневреності власного капіталу & $>0$ збільшення & 0,50 & 0,68 & 0,93 \\
\hline \multicolumn{5}{|c|}{ Показники ділової активності підприємства } \\
\hline Коефріцієнт оборотності активів & збільшення & $\mathrm{x}$ & 2,01 & 1,94 \\
\hline Коефіцієнт оборотності дебіторської заборгованості & збільшення & $\mathrm{x}$ & 4,72 & 4,89 \\
\hline Строк погашення дебіторської заборгованості, днів & зменшення & $\mathrm{x}$ & 76,3 & 73,6 \\
\hline Коефріцієнт оборотності основних засобів & збільшення & $\mathrm{x}$ & 3,97 & 4,12 \\
\hline Коефріцієнт оборотності власного капіталу & збільшення & $x$ & 4,6 & 3,7 \\
\hline
\end{tabular}

Джерело: складено авторами на основі даних підприємства 
Модель визначення типу фінансової стійкості

Таблиця 4

\begin{tabular}{|c|c|c|c|c|c|}
\hline \multirow{2}{*}{ № } & $\begin{array}{c}\text { Показники, } \\
\text { надлишок (+) } \\
\text { нестача (-) }\end{array}$ & $\begin{array}{c}\text { Абсолютна } \\
\text { фінансова } \\
\text { стійкість }\end{array}$ & $\begin{array}{c}\text { Нормальна } \\
\text { фінансова } \\
\text { стійкість }\end{array}$ & $\begin{array}{c}\text { Нестійкий } \\
\text { фінансовий } \\
\text { стан }\end{array}$ & $\begin{array}{c}\text { Кризовий } \\
\text { фрінансовий } \\
\text { стан }\end{array}$ \\
\hline 1 & $\pm \mathrm{BOK}=\mathrm{BOK}-3$ & $\pm \mathrm{BOK} \geq 0 ;$ & $\pm \mathrm{BOK}<0 ;$ & $\pm \mathrm{BOK}<0 ;$ & $\pm \mathrm{BOK}<0 ;$ \\
\hline 2 & $\pm \Phi \mathrm{O}=\Phi \mathrm{K}-3$ & $\pm \Phi \mathrm{K} \geq 0 ;$ & $\pm \Phi \mathrm{K}<0 ;$ & $\pm \Phi \mathrm{K}<0 ;$ & $\pm \Phi \mathrm{O}<0 ;$ \\
\hline 3 & $\pm 3 \mathrm{~B}=3 \mathrm{~B}-3$ & $\pm 3 \mathrm{~B} \geq 0 ;$ & $\pm 3 \mathrm{~B}<0 ;$ & $\pm 3 \mathrm{~B}<0 ;$ & $\pm 3 \mathrm{~B}<0 ;$ \\
\hline
\end{tabular}

Джерело: складено авторами на основі [6; 7]

Таблиця 5

Розрахунок фрінансової стійкості ПрАТ "Лантманнен Акса"

\begin{tabular}{|c|c|c|c|}
\hline & $\mathbf{2 0 1 8}$ & $\mathbf{2 0 1 9}$ & $\mathbf{2 0 2 0}$ \\
\hline Запаси & 49151 & 50462 & 41881 \\
\hline \pm ВОК & -29932 & -48574 & -15472 \\
\hline \pm ФК & 142095 & 171760 & 186613 \\
\hline \pm ЗВ & 23416 & 68819 & 57616 \\
\hline
\end{tabular}

Джерело: складено авторами на основі даних підприємства

32018 по 2020 рік підприємство ПрАТ "Лантманнен Акса має стабільну фрінансову стійкість, проте власний оборотний капітал підприємства лишався від'ємним.

SWOT-аналіз - це метод оцінки макро і мікро фракторів, що впливають на розвиток та фрінансову стабільність підприємства. Дана методика дозволяє оцінити сильні і слабкі сторони підприємства, знайти нові можливості для підприємства і виявити можливі загрози, які впливають на фрінансові ризики. (табл.6).

Після проведеного SWOT-аналізу, можна стверджувати що, підприємство має багато сильних сторін, 3 можливостей можна виділити:

- Появу нових споживачів

- Ріст експорту

- Зріст попиту на даний вид продукції

Проте також підприємство має і певні загрози, над якими потрібно працювати, щоб уникнути фрінансових ризиків, такі як:

- Зниження купівельної спроможності через COVID-19

- Збільшення собівартості через підвищення комунальних платежів

- Поява нових конкурентів.

Останнім кроком для прорахунку фрінансового стану потрібно прорахувати можливість настання банкрутства.

В науковій літературі існує велика кількість моделей визначення ймовірності банкрутства, як зарубіжних, так і вітчизняних:

- модель Таффрлера;

- модель Мартиненко;

- модель Альтмана.
Модель Тафрфлера запропонував британський вчений Тафффлер у 1977р.

Модель має наступний вигляд:

$$
\begin{gathered}
Z=0.53^{*} X_{1}+0.13^{*} X_{2}+0.18^{*} X_{3}+0.16^{*} X_{4} \\
\text { Джерело: [16] }
\end{gathered}
$$

де $X_{1}$ - прибуток до виплат/поточні зобов'язання

$\mathrm{X}_{2}$ - поточні активи/зобов'язання

$\mathrm{X}_{3}$ - поточні зобов'язання/загальна вартість активів

$\mathrm{X}_{4}$ - виручка від реалізації/загальна вартість активів.

За останні роки за моделлю Тафрфлера, його коесріцієнт більше 0,7 , що говорить про те що у фрірмі хороші довгострокові перспективи.

Українськими вченими розроблені методики прогнозування банкрутства для підприємств певних галузей. Модель Мартиненка визначення імовірності банкрутства має наступний вигляд:

$$
\begin{aligned}
\mathrm{K}_{\mathrm{i} 6}= & \mathrm{K}_{\text {пл }}+3,33^{\star} \mathrm{K}_{\mathrm{a}}+5,71 * \mathrm{~K}_{\text {рвк }} \\
& \text { Джерело: [17] }
\end{aligned}
$$

де $\mathrm{K}_{\text {пл }}$ - коесріцієнт поточної ліквідності,

$\mathrm{K}_{\mathrm{a}}$ - коефріцієнт автономії,

$\mathrm{K}_{\text {рвк }}$ - коефріцієнт рентабельності власного капіталу.

Нормативні значення:

6,0 і вище - низька ймовірність банкрутства;

5,99-5,30 - можлива;

5,29-3,49 - висока;

У 2019 спостерігається досить високий фрінансовий ризик, проте у 2020 році йде зменшення до ризику банкрутства. 
SWOT-аналіз ПрАт «Лантманнен Акса»

Таблиця 6

\begin{tabular}{|c|c|}
\hline Сильні сторони & Слабкі сторони \\
\hline 1 & 2 \\
\hline $\begin{array}{l}\text { - Натуральність усіх фррукт } \\
\text { горіхових наповнювачів вів } \\
\text { - Велика соціальна складо } \\
\text { підприємницької діяльності }\end{array}$ & $\begin{array}{l}\text { - Не має чіткої асоціації з ТМ «АХА» у споживачів } \\
\text { - Має образ не якісного, дешевого товару } \\
\text { серед споживачів } \\
\text { - Налагоджені асортиментні стратегії конкурентів }\end{array}$ \\
\hline $\begin{array}{l}\text { - Великий досвід роботи ПрАт “Лантманнен } \\
\text { Акса” на ринку (32 років) } \\
\text { - Якість продукції підтверджена сертифрікатами } \\
\text { - Відносно висока швидкість впровадження } \\
\text { нових технологій } \\
\text { - Залучення висококваліфікованих кадрів } \\
\text { - Успішне залучення іноземних інвестицій у } \\
\text { компанію } \\
\text { - Роздрібна ціна нижча, ніж у конкурентів }\end{array}$ & $\begin{array}{l}\text { - Неповнота використання можливих каналів } \\
\text { комунікації } \\
\text { - Не достатня інорормованість споживачів } \\
\text { про благодійну діяльність компанії } \\
\text { - Відсутність визначеності та спрямованості } \\
\text { на певну цільову аудиторію }\end{array}$ \\
\hline Можливості & Загрози \\
\hline 1 & 2 \\
\hline $\begin{array}{l}\text { - Зростання обізнаності ТМ, через тренди } \\
\text { на усвідомлене споживання екологічних та } \\
\text { корисних для здоров'я продуктів } \\
\text { - Поява нових споживачів, за рахунок } \\
\text { росту сегменту маркетплейсів для надання } \\
\text { інформації та послуг в мережі інтернет } \\
\text { - Ріст експорту сухих сніданків } \\
\text { - Збільшення попиту на харчові товари (у } \\
\text { тому числі на вівсянку), так як соціальні } \\
\text { стандарти життя населення України зросли } \\
\text { - Відказ від мінеральної олії - поштовх } \\
\text { компанії в інвестування у еко-імідж }\end{array}$ & $\begin{array}{l}\text { - Поява нових конкурентів, за рахунок } \\
\text { відсутності високих бар'єрів входу на ринок } \\
\text { - Ріст вибагливості споживачів } \\
\text { Заборона на використання пальмової олії, } \\
\text { сприяє підвищенню собівартості товару } \\
\text { - Низька лояльність молодої групи } \\
\text { споживачів до торгової марки } \\
\text { - Збільшення собівартості вир-ва через } \\
\text { підвищення тарифрів енергопостачання } \\
\text { - Зниження купівельної спроможності } \\
\text { споживачів сухих сніданків, через впровадження } \\
\text { карантину на усій території України з 2020 року }\end{array}$ \\
\hline
\end{tabular}

Джерело: складено авторами на основі даних підприємства

Таблиця 7

Дані для розрахунку моделі Таффрлера для ПрАТ «Лантманнен Акса» 2018-2020 рр.

\begin{tabular}{|c|c|c|c|}
\hline & $\mathbf{2 0 1 8}$ & $\mathbf{2 0 1 9}$ & $\mathbf{2 0 2 0}$ \\
\hline $\mathrm{X}_{1}$ & 0,224 & 0,216 & 0,277 \\
\hline $\mathrm{X}_{2}$ & 0,146 & 0,132 & 0,155 \\
\hline $\mathrm{X}_{3}$ & 0,044 & 0,046 & 0,041 \\
\hline $\mathrm{X}_{4}$ & 0,298 & 0,298 & 0,311 \\
\hline $\mathrm{Z}$ & 0.712 & 0.692 & 0.784 \\
\hline
\end{tabular}

Джерело: складено авторами на основі даних підприємства

Таблиця 8

Дані для розрахунку моделі Мартиненко для ПрАТ «Лантманнен Акса» 2018-2020 рр.

\begin{tabular}{|c|c|c|c|}
\hline & $\mathbf{2 0 1 8}$ & $\mathbf{2 0 1 9}$ & $\mathbf{2 0 2 0}$ \\
\hline $\mathrm{K}_{\text {пл }}$ & 2,97 & 2,39 & 2,47 \\
\hline $\mathrm{K}_{\mathrm{a}}$ & 1,16 & 1,46 & 1,73 \\
\hline $\mathrm{K}_{\text {рвк }}$ & 1,628 & 1,439 & 1,291 \\
\hline $\mathrm{K}_{\text {іб }}$ & 5,76 & 5,29 & 5,49 \\
\hline
\end{tabular}

Джерело: складено авторами на основі даних підприємства
Модель Альтмана (Altman model) - алгоритм інтегральної оцінки загрози банкрутства підприємства, заснований на комплексному дослідженню найважливіших показників, що діагностують кризовий фрінансовий стан. $\mathrm{Z}=0,717 \mathrm{X}_{1}+0,847 \mathrm{X}_{2}+3,107 \mathrm{X}_{3}+0,420 \mathrm{X}_{4}+0,998 \mathrm{X}_{5}$ (3) Джерело: [18]

де $\mathrm{X}_{1}$ - Оборотний капітал/Активи

$\mathrm{X}_{2}$ - Чистий прибуток/Активи

$\mathrm{X}_{3}$ - Операційний прибуток/Активи

$\mathrm{X}_{4}-$ Власний капітал/Зобов'язання

$\mathrm{X}_{5}-$ Дохід від продажу/Активи

$Z>2,9$ - зона фрінансової стійкості («зелена» зона)

$1,23<Z<2,9-$ зона невизначеності («сіра» зона)

$Z<1,23$ - зона фрінансового ризику («червона» зона)

За допомогою даної моделі, можна, стверджувати, що підприємству не загрожує банкрутство, тому що показники знаходяться на досить високих позиціях, також прослідковується тенденція до збільшення показників. 
Таблиця 9

Дані для розрахунку моделі Альтмана для ПрАТ «Лантманнен Акса» 2018-2020 рр.

\begin{tabular}{|c|c|c|c|}
\hline & $\mathbf{2 0 1 8}$ & $\mathbf{2 0 1 9}$ & $\mathbf{2 0 2 0}$ \\
\hline $\mathrm{X}_{1}$ & 0,42 & 0,43 & 0,40 \\
\hline $\mathrm{X}_{2}$ & 0,08 & 0,08 & 0,10 \\
\hline $\mathrm{X}_{3}$ & 0,53 & 0,40 & 0,77 \\
\hline $\mathrm{X}_{4}$ & 0,37 & 0,46 & 0,88 \\
\hline $\mathrm{X}_{5}$ & 1.84 & 1.85 & 1.93 \\
\hline $\mathrm{Z}$ & 3,24 & 3,22 & 4,08 \\
\hline
\end{tabular}

Джерело: складено авторами

на основі даних підприємства

За допомогою трьох моделей оцінки настання банкрутства, можна зробити висновок, що компанія має доволі стійке фрінансове положення.

Розробка програм сталого розвитку підприємства ПрАТ «Лантманнен Акса» здійснюється працівниками підрозділу стратегічного планування та досліджень, дані програми розробляються 3 метою впровадження енерго-, ресурсозберігаючих та маловідходних технологій промислового виробництва, зменшення рівня енергоємності виробництва, технологічної модернізації виробництва шляхом впровадження новітніх наукових досягнень, створення програм 3 попередженню виникнення фрінансових ризиків, здійснення заходів, спрямованих на вдосконалення підготовки, перепідготовки та підвищення кваліфрікації фрахівців з вищою освітою, кваліфрі- кованих робітників, професійного розвитку працівників застосування сучасних механізмів стимулювання високопродуктивної праці, оздоровлення працівників та екологічності виробництва.

Поточна програма сталого розвитку підприємства ПрАТ «Лантманнен Акса» спрямована на такі напрями сталого розвитку, підвищення якості та доступності послуг, забезпечення здорових та безпечних умови праці, охорони навколишнього середовища та енергоефективності (рис. 1).

Забезпечення даної програми здійснюється за допомогою стабільного фрінансового стану. Тому потрібно дві програми правильно з'єднувати, для того щоб акумулювати вільні кошти, отримані від програми по зниженню срінансових ризиків, в програму сталого розвитку підприємства (рис. 1).

Згідно результатів дослідження фрінансовоекономічного стану підприємства в умовах сталого розвитку, можна стверджувати, що концепція, якої дотримується компанія призводить до того, що фрінансово-економічний аспект стратегії доволі успішний і це можна помітити 3 розрахованих показників. Разом 3 тим, існують такі показники як: коефіцієнт срінансової автономії, рентабельність сукупного капіталу, які знаходяться на гранично допустимій позначці.

Отже, було вирішено шляхом удосконалення стратегії сталого розвитку підприємства «Лантманнен Акса», створити нову корисну

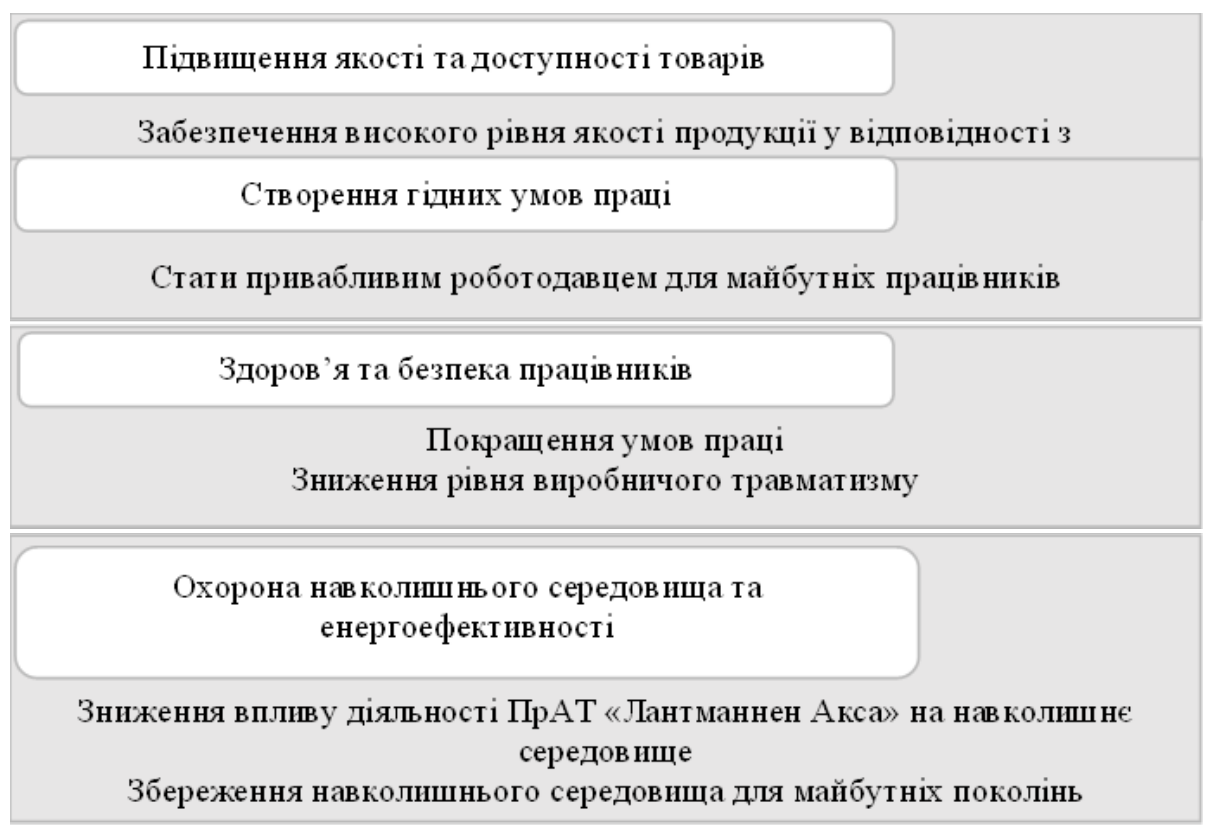

Рис. 1. Поточна програма сталого розвитку ПрАТ «Лантманнен Акса»

Джерело: складено авторами на основі даних підприємства 
продукцію, яка дозволить покращити фрінансово-економічні показники підприємства, а також позитивно вплине на інші аспекти стратегії сталого розвитку.

Висновки. Відповідно до мінливих умов ринку та посилення конкурентних сил, підприємство має розробляти чітку та досить інтегровану систему забезпечення стійкого розвитку.

За результатами аналізу можна сказати, що ПрАТ «Лантманнен Акса» має непогану концепцію сталого розвитку, яка на даний момент приносить успіхи у фрінансово-економічній складовій. Такі показники, як: коефріцієнт фрінансової стійкості, коефріцієнт абсолютної ліквідності, коефріцієнт швидкої ліквідності знаходяться на досить високому рівні. Проте, в той же час аналіз показав, що $€$ напрямки, в яких слід розвиватись та як наслідок удосконалювати стратегію сталого розвитку підприємства.

\section{СПИСОК ВИКОРИСТАНИХ ДЖЕРЕЛ:}

1. Beer S., Wiley J. Cybernetics and management. New York, 1968. 214 p.

2. Freeman C. The "National System of Innovation" in historical perspective. Cambridge Journal of Economics. 1995. P. 5-24.

3. Васюк Н.В. Формування механізму стійкого розвитку машинобудівних підприємств. Інноваційна економіка. 2012. С. 125-128.

4. Гальчак Х.Р. Забезпечення сталого розвитку підприємства як основа формування соціальної відповідальності. Вісник Національного університету "Львівська політехніка". Серія : Проблеми економіки та управління : збірник наукових праць. 2016. С. 69-74.

5. Демиденко Л.М. Концептуальні підходи до забезпечення стійкого розвитку підприємства. Наукові праці Полтавської державної аграрної академії. 2013. С. 92-96.

6. Невмержицький Я. Фінансовий ризик та дивідендна політика підприємства. Ринок цінних паперів Україні. 2006. С. 3-4.

7. Скакальський Ю.С. Контролінг фінансових ризиків підприємств : дис. ... канд. ек. наук : 08.00.08. Київ, 2016. $231 \mathrm{c}$.

8. Зоріна О.А. Методи аналізу фрінансових ризиків. Міжнародний збірник наукових праць. 2011. № 2. C. 221-229.

9. Лазоренко Т., Шолом І. Теоретичні засади концепції управління стійким розвитком підприємства. Галицький економічний вісник. 2020. № 6. С. 175-184.

10. Штайнхоффр Д., Берджес Д. Основы управления малым бизнесом. Москва : БИНОМ, 1997. 495 с.

11. Грабовый П.Г., Петрова С.Н., Полтавцев С.И. Риски в современном бизнесе. Москва : Аланс, 1994. 200 с.

12. Дорош О.Б. Основні завдання та напрями аудиту фрінансової діяльності підприємства [Електронний ресурс]: збірник / Наука молода. № 12. Київ, 2009. URL: http://www.nbuv.gov.ua/portal/Soc_Gum/ Menedzhment/2009_12/Doroch

13. Державна служба статистики України. URL: http://www.ukrstat.gov.ua/

14. Тупалсьска О. Коронавірус 2020 та харчова безпека: чи буде Україна з продовольством, а бізнес 3 гривнею. Агрополіт - гаряча агрополітика. URL: https://agropolit.com/spetsproekty/721-koronavirus-2020-taharchova-bezpeka-chi-bude-ukrayina-z-prodovolstvom-a-biznes-z-grivneyu

15. Шевчук П. Пластівці заходять на територію круп. Економічна правда. URL: https://www.epravda.com.ua/ columns/2018/12/14/643517/

16. Taffler R., Tisshaw H. Going, going, gone - four factors which predict. Accountancy. 1977. P. 52-55.

17. Мартиненко В.П. Стратегія життєздатності промислових підприємств : (монограсрія). Київ : Центр навч. л-ри, 2006. 324 с.

18. Altman E.I. Financial Ratios, Discriminant Analysis and the Prediction of Corporate Bankruptcy. The Journal of Finance. 1968. № 4. P. 589-609. DOI: https://doi.org/10.2307/2978933

\section{REFERENCES:}

1. Beer S., Wiley J. (1968) Cybernetics and management. New York, $214 \mathrm{p}$.

2. Freeman C. (1995) The "National System of Innovation" in historical perspective. Cambridge Journal of Economics, pp. 5-24.

3. Vasyuk N.V. (2012) Formuvannya mehanizmu stiykoho pozvitku mashinobudivnyh pidpriemstv [Formation of the mechanism of sustainable development of machine-building enterprises]. Innovatsiyna ekonomika, no, 10. pp. 125-128. (in Ukrainian) 
4. Halchak H.R. (2016) Zabezpechennya stalogo rozvitku pidpriemstva yak osnova formuvannya sotsialnoyi vidpovidalnosti [Ensuring sustainable development of the enterprise as a basis for the formation of social responsibility]. Visnyk Natsionalnogo universytetu "Lvivska politehnika". Seriya: Problemy ekonomiky ta upravlinnya: zbirnyk naukovykh prats, no. 847, pp. 69-74. (in Ukrainian)

5. Demydenko L.M. (2013) Konceptualni pidhody do zabezpechennya stiykoho rozvitku pidpriemstva [Conceptual approaches to ensuring sustainable development of the enterprise]. Naukovy pratsi Poltavskoyi derzhavnoyi ahrarnoyi akademiyi. Seriya: Ekonomichni nauky, no. 2(7), pp. 92-96. Available at: http://www.pdaa.edu.ua/sites/ default/files/nppdaa/7.1/92.pdf (in Ukrainian)

6. Nevmerzhytskiy Ya. (2006) Finansoviy ryzyk ta dyvidendna polityka pidpryemstva [Financial risk and dividend policy of the enterprise]. Rynok tsinnyh paperiv Ukrayiny, no. 5, pp. 3-4. (in Ukrainian)

7. Skakalskiy Yu.S. (2016) Kontroling finansovyh ryzykiv pidpryemstv [Controlling financial risks of enterprises], 231 p. (in Ukrainian)

8. Zorina O.A. (2011) Metody analizu finansovyh ryzykiv [Methods of financial risk analysis], no. 2(20), pp. 221-229. Available at: http://eztuir.ztu.edu.ua/jspui/bitstream/123456789/4746/1/21.pdf

9. Lazarenko T., Sholom, I. (2020) Teoretychni zasady koncepciyi upravlinnya stiykum rozvytkom pidpriemstva [Theoretical fundamentals of the concept of managemgent of sustainable enterprise development]. Halytskiy ekonomichniy visnyk, no. 6, pp. 175-184. Available at: https://galicianvisnyk.tntu.edu.ua/pdf/67/924.pdf (in Ukrainian)

10. Shtaynhoff D., Berdzhes D. (1997) Osnovy upravleniya malym biznesom [Basics of small business management]. Moscow: BINOM, 495 p. (in Russian)

11. Hraboviy P.G., Petrova S.N., Poltavtsev S.I. (1994) Riski v sovremennom biznese [Risks in modern business]. Moscow: Alans, 200 p. (in Russian)

12. Dorosh O.B. (2009) Osnovni zavdannya ta napryamy audytu finansovoyi diyalnosti pidpriemstva [The main tasks and areas of audit of financial activities of the enterprise]. Available at: http://www.nbuv.gov.ua/portal/Soc_ Gum/Menedzhment/2009_12/Doroch.htm

13. Derzhavna sluzhba statystyky Ukrayiny. Available at: http://www.ukrstat.gov.ua/

14. Tupalska O. (2020) Koronavirus 2020 ta harchova bezpeka: chy bude Ukrayina z prodovolstvom, a biznes z hrivneyu [Coronavirus 2020 and food security: will Ukraine be with food and business with hryvnia]. Available at: https://agropolit.com/spetsproekty/721-koronavirus-2020-ta-harchova-bezpeka-chi-bude-ukrayina-z-prodovolstvom-a-biznes-z-grivneyu

15. Shevchuk P. (2018) Plastivtsi zahodyat' na terytoriyu krup [Flakes enter the territory of cereals]. Ekonomichna pravda. Available at: https://www.epravda.com.ua/columns/2018/12/14/643517/

16. Taffler R., Tisshaw H. (1977) Going, going, gone - four factors which predict. Accountancy, pp. 50-54.

17. Martynenko V.P. (2006) Strategiya zhittezdatnosti promislovyh pidpryemstv [Sustainability strategy of industrial enterprises]. Kyiv: Tsentr navch. I-ry, 324 p. (in Ukrainian)

18. Altman E.I. (1968) Financial Ratios, Discriminant Analysis and the Prediction of Corporate Bankruptcy. The Journal of Finance, no. 4, pp. 589-609. DOI: https://doi.org/10.2307/2978933 